University of Wollongong

Research Online

Faculty of Engineering and Information

Faculty of Engineering and Information

Sciences - Papers: Part A

Sciences

$1-1-2016$

Comparison of resting energy expenditure between cancer subjects and healthy controls: a meta-analysis

Thi Yen Vi Nguyen

University of Wollongong

Marijka Batterham

University of Wollongong, marijka@uow.edu.au

Cheree Edwards

University of Wollongong

Follow this and additional works at: https://ro.uow.edu.au/eispapers

Part of the Engineering Commons, and the Science and Technology Studies Commons

Research Online is the open access institutional repository for the University of Wollongong. For further information contact the UOW Library: research-pubs@uow.edu.au 


\title{
Comparison of resting energy expenditure between cancer subjects and healthy controls: a meta-analysis
}

\author{
Abstract \\ There is conflicting evidence surrounding the extent of changes in resting energy expenditure (REE) in \\ cancer. This meta-analysis aimed to establish the mean difference in REE, as kilojoules per kilogram fat- \\ free mass, among cancer patients when compared to healthy control subjects. The secondary aim was to \\ determine differences among different cancer types. PubMed, Cochrane Library, Medline, Science Direct, \\ Scopus, Web of Science, Wiley Online Library, and ProQuest Central were searched from the earliest \\ records until March 2014. Studies were included if measured REE was reported as kilojoules or \\ kilocalories per kilogram fat-free mass (FFM) in adult subjects with cancer. Twenty-seven studies were \\ included in the meta-analysis. Fourteen studies included both cancer $(n=1453)$ and control $(n=1145)$ \\ groups. The meta-analysis shows an average increase in REE of 9.66 (95\% confidence interval: 3.34, \\ $15.98) \mathrm{kJ} / \mathrm{kgFFM} /$ day in cancer patients when compared to control subjects. Heterogeneity was detected \\ $(P<0.001)$ which suggest variations in REE among cancer types. Elevations are most noticeable in \\ patients with cancers of metabolically demanding organs.

\section{Keywords} \\ energy, cancer, resting, comparison, between, expenditure, subjects, analysis, healthy, meta, controls

\section{Disciplines} \\ Engineering | Science and Technology Studies

\section{Publication Details} \\ Nguyen, T., Batterham, M. J. \& Edwards, C. (2016). Comparison of resting energy expenditure between \\ cancer subjects and healthy controls: a meta-analysis. Nutrition and Cancer: an international journal, 68 \\ (3), 374-387.
}


Comparison of resting energy expenditure between cancer subjects and healthy controls: A meta-analysis.

Thi Yen Vi Nguyen,

School of Medicine

University of Wollongong

Marijka J Batterham,

National Institute for Applied Statistics Research Australia

School of Mathematics and Applied Statistics

University of Wollongong

Australia

Cheree Edwards

School of Medicine

University of Wollongong 
ABSTRACT

There is conflicting evidence surrounding the extent of changes in resting energy expenditure in cancer. This meta-analysis aimed establish the mean difference in resting energy expenditure, as kilojoules per kilogram fat-free mass, among cancer patients when compared to healthy control participants. The secondary aim was to determine differences among different cancer types.

PubMed, Cochrane Library, Medline, Science Direct, Scopus, Web of Science, Wiley Online Library, and ProQuest Central were searched from the earliest records until March 2014. Studies were included if measured resting energy expenditure was reported as kilojoules or kilocalories per kilogram fat-free mass in adult subjects with cancer. Twenty seven studies were included in the meta-analysis. Fourteen studies included both cancer $(n=1453)$ and control $(n=1145)$ groups. The meta-analysis shows an average increase in resting energy expenditure of $9.66(95 \% \mathrm{Cl} 3.34$, $15.98) \mathrm{kJ} / \mathrm{kgFFM} /$ day in cancer patients when compared to control participants. Heterogeneity was detected $(p<0.001)$ which suggest variations in resting energy expenditure among cancer types. Elevations are most noticeable in patients with cancers of metabolically demanding organs.

\section{Comparison of resting energy expenditure between cancer subjects and healthy controls: A meta-analysis}

\section{INTRODUCTION}

Changes in resting energy expenditure (REE) in cancer patients have been a controversial topic in literature. Substantial evidence supports elevations in REE during the tumour-bearing state. Elevated REE can potentially promote weight loss which can produce suboptimal clinical outcomes and increase morbidity and mortality risk[1]. Furthermore, elevated REE in conjunction with poor oral intake typically seen in cancer patients serve a significant role in accelerating weight loss and progressing to the development of malnutrition and cancer cachexia[2].

Current published findings depict inconsistencies in metabolic changes. Various authors propose that different cancers cause varying degrees of metabolic derangements. Fredrix et al[3] observed greater elevation of REE in lung cancer patients than gastric-colorectal cancer patients. Cao et al[4] found elevated REE in patients with oesophageal, gastric, pancreatic and lung cancers when compared to a healthy control group, whereas colorectal cancer patients showed no elevation in REE. Merli et al[5] and Xu et al[6] saw increased REE in patients with hepatocellular carcinoma and urologic cancer, respectively. However, authors for example Fearon et al[7] observed no significant differences in REE in colon and lung cancer patients and Trutschnigg et al[8] reported insignificant differences in advanced cancer patients. 
Energy expenditure is the result of metabolic activities from various body tissues and organs. Major organs, such as the lungs and liver, are metabolically demanding and contribute to REE due to its continuous functioning and higher energy demands to perform metabolic processes irrespective of the body's physical state and resting conditions. Fat free mass (FFM) is considered to be the largest contributor to REE suggested to provide $53-88 \%$ of REE variation[9, 10]. It would be valid to conclude that REE is decreased if loss of FFM becomes apparent under any circumstances, including cancer. This has not been the case as weight loss is frequently reported and observed in cancer patients. Weight loss associated with cancer is considered undesirable due to losses from either fat mass, FFM or both which serve important sources of energy during periods of acute hypermetabolism[1]. It has also been hypothesised that muscular atrophy typically observed in clinical settings is associated with poor tolerance of cancer treatment procedures and, hence, poor clinical outcomes[2].

Tumour-bearing is proposed to elevate energy expenditure. However, there is uncertainty surrounding this. It has been suggested[2] that the tumour itself is unlikely to be the direct cause of elevated energy expenditure as tumours rarely contribute more than $5 \%$ of body weight. A plausible explanation may be that presence of tumours can exert an indirect effect on energy expenditure. The production of biochemical mediators stimulated by tumour growth may alter metabolism[2]and promote the inflammatory response which could contribute to hypermetabolism[11].

Although nutritional adequacy may be achieved to limit weight loss from FFM, the uncertainty of the metabolic environment may impede the maintenance or restoration of FFM[2, 12]. Identifying the extent to which REE is altered and understanding the cancer subtypes which cause the greatest increases in REE is important from a clinical perspective to limit anticipated weight loss as FFM and optimise clinical outcomes. The primary aim of this study was to establish the difference in REE between cancer patients and healthy controls. The secondary aim was to distinguish the differences in REE between cancer subgroups. As FFM is considered to be a large contributor to REE[9], it is appropriate to use measured REE per $\mathrm{kg} F F M$. The use of healthy control groups was deemed appropriate to use as the standard for comparison to determine metabolic changes in cancer patients.

\section{METHODS}

\section{Literature search}

Literature searches were conducted by VN using the databases PubMed, Cochrane Library, Medline, Science Direct, Scopus, Web of Science, Wiley Online Library, and ProQuest Central from the earliest record to March 2014 to obtain as many potentially relevant studies as possible. The following search terms, 'resting energy expenditure', 'resting metabolic rate', 'basal metabolic rate', 'cancer', and 'neoplasm' were used. Reference lists from included studies were reviewed to obtain additional relevant articles. The journals, Nutrition and Cancer, and Cancer and Metabolism were also searched using the above search terms. 


\section{Study selection}

Studies in which the title included one or more of the search terms were obtained from the literature search. The abstracts of the studies were reviewed by VN and MB for relevance. Studies were included if REE was expressed as kilojoules (kJ) or kilocalories (kcal) per kilogram FFM (REE/FFM), body composition was measured, participants were adult humans with cancer, healthy control groups were defined and used, statistical values presented as mean \pm standard deviation (mean $\pm S D$ ) or mean \pm standard error of the mean (mean \pm SEM), and studies were published in English. Studies that measured REE, as REE/FFM, in cancer patients but did not include control groups were also included. Baseline REE measurements from intervention (pre-test/post-test) studies were included in the data set.

\section{Data extraction}

Study characteristics including the authors, source, publication year, cancer type, and the use of control subjects were tabulated. Baseline REE, presented as $\mathrm{kJ}$ or kcal per kg FFM, the number and type of subjects were collated into a Microsoft Office Excel spreadsheet. The method used to assess REE and the method used to assess body composition were also recorded, these were divided into more accurate and reliable methods (Dual energy $x$-ray absorptiometry DEXA, total body water, or total body potassium) and field methods (bioelectrical impedance assessment or skinfold anthropometry) to assess study quality. The baseline REE was the measurement prior to the cancer patients' undergoing various treatments.

\section{Statistical analysis}

The baseline REE values and the number of participants (cancer patients and healthy controls) were used to complete the meta-analysis conducted by MB. The meta-analysis was conducted using STATA/IC V14 ( StataCorp LP, College Station, Tx) using the metan command[13]. All meta-analyses were conducted using random effects as heterogeneity was anticipated. Differences in REE amongst cancer types were also determined through a subgroup analysis. In order to account for the use of the same control subjects for some studies the sample sizes were divided by the number of times the control group was used[14]. Additionally independent subgroups within a study were considered separately in the primary analysis[15]. In order to investigate potential confounding variables secondary analyses were also conducted to investigate the effect of healthy versus hospitalised/disease controls, weight losing versus weight stable cancer patients and controls, gender, and year of publication (pre or after 2000). Results are presented as weighted mean differences (WMD) between groups with $95 \%$ confidence intervals $(95 \% \mathrm{Cl})$. Statistical significance of the differences between the groups is calculated using metaregression (metareg in STATA V14.0). Study quality comparing those studies using a more accurate and reliable measure of body composition assessment compared with a field measure was also assessed using metagression.

\section{RESULTS}

\section{Search results}

Figure 1 shows a flowchart of the extraction process. A total of 205 abstracts were obtained from the initial literature search, 178 abstracts were excluded on the 
following basis: 85 studies expressed REE as kJ or kcal per day body weight or body cell mass, did not measure REE or body composition, or did not present data as mean $\pm S D$ or mean $\pm S E M ; 56$ were either review articles, educational papers, poster presentations, case reports, editorials or supplementary material; 12 studies were published in a language other than English; 11 studies were not on the subject of cancer; 7 studies were on animals; and 7 studies involved children. Twenty-seven studies were considered relevant for inclusion in this review[3-8, 11, 16-35] (Table 1). Of these 27 studies, 14 studies included a healthy control group and the data from these studies were used to generate the meta-analysis (Figure 2). Two studies used the cancer patients as their own control.

\section{INSERT FIGURE 1}

\section{INSERT TABLE 1}

\section{INSERT FIGURE 2}

The forest plot shown in Figure 2 represents data obtained from 1453 cancer patients and 1145 control participants. The mean difference in REE/FFM between cancer patients and healthy controls is $9.66 \mathrm{~kJ} / \mathrm{kgFFM} /$ day $(95 \% \mathrm{Cl} 3.34,15.98)$ which suggests an overall increase in REE in cancer patients. The test for heterogeneity $\left(\mathrm{Chi}^{2}=474.01 \mathrm{p}<0.001\right)$ suggested significant variation in REE/FFM among cancer types, the funnel plot presented in Figure 3 shows no evidence of publication bias but clearly emphasises the outlying value of the Wu et al study[35].

\section{INSERT FIGURE 3}

The subgroup analysis (Figure 4) represents data from 12 of the 14 studies included in the meta-analysis. Two studies were not included in the analysis as they did not distinguish between cancer subtypes. The subgroup analysis derived mean differences in REE for 6 cancer types. Lung, head and neck/oesophageal, pancreatic and urological cancers had elevations of $6.52 \mathrm{~kJ} / \mathrm{kg} F F M /$ day, $21.06 \mathrm{~kJ} / \mathrm{kg} \mathrm{FFM} /$ day, $9.51 \mathrm{~kJ} / \mathrm{kg} \mathrm{FFM} /$ day and $3.86 \mathrm{~kJ} / \mathrm{kg}$ FFM/day, respectively. Liver cancer illustrated the greatest elevation of $22.68 \mathrm{~kJ} / \mathrm{kg}$ FFM/day. All groups were significantly elevated with the exception of the gastric/colon cancer subgroup which showed an increase of $1.99 \mathrm{~kJ} / \mathrm{kg} /$ day FFM $(95 \% \mathrm{Cl}-0.58,4.53)$. The head, neck and oesophageal group elevation while high was not significant when the Wu study was included however the funnel plot demonstrates that this study is a clear outlier (consistent with the funnel plot in Figure 5), reanalysis without this study showed an elevation in the head, neck and oesophageal group of $6.04 \mathrm{~kJ} / \mathrm{kg} /$ day FFM $(95 \% \mathrm{Cl} 2.27,9.81)$ indicating that REE is increased in this group. There was no evidence of publication bias (asymmetry) in the subgroup analysis (Figure 5).

\section{INSERT FIGURE 4}

\section{INSERT FIGURE 5}

When controls were divided into healthy (WMD 14.74 95\% Cl 1.99,27.50 $\mathrm{kJ} / \mathrm{kgFFM} /$ day) or hospitalised/diseased (WMD 4.51 95\% Cl 1.00,8.01) elevation in REE in cancer patients were still significantly elevated in both groups and there was no difference between groups $P=0.264$. While there was no statistically significant difference between those identifying weight stable cancer patients and controls (WMD 6.55 95\% Cl 4.21, $8.90 \mathrm{~kJ} / \mathrm{kg}$ FFM/day) and those identifying weight losing 
cancer patients and controls (WMD $4.4995 \% \mathrm{Cl}-0.61,9.58 \mathrm{~kJ} / \mathrm{kg} \mathrm{FFM} /$ day)

$\mathrm{P}=0.628$, the elevation in the weight losing group only approached significance

$\mathrm{P}=0.084$. There was no effect of year of publication when a subgroup analysis was conducted dividing the dataset into publication year prior to (WMD $5.4595 \% \mathrm{Cl} 1.54$, $9.35 \mathrm{~kJ} / \mathrm{kg}$ FFM/day) or after 2000 (WMD $23.5195 \% \mathrm{Cl} 7.70,39.32 \mathrm{~kJ} / \mathrm{kg} \mathrm{FFM} /$ day) $\mathrm{P}=0.092$, the wide $\mathrm{Cl}$ for the post 2000 publications was influenced by the Wu et al paper (without this paper the WMD for the post 2000 papers was $4.6095 \% \mathrm{Cl} 3.21$, $5.98 \mathrm{~kJ} / \mathrm{kg}$ FFM day). Only 2 studies reported values by gender[29, 32], there was no significant effect using meta regression (males WMD $-3.3395 \% \mathrm{Cl}-10.14,3.47 \mathrm{~kJ} / \mathrm{kg}$ FFM/day and females WMD $3.7595 \% \mathrm{Cl}-2.79,10.29 \mathrm{~kJ} / \mathrm{kg} \mathrm{FFM} /$ day) $\mathrm{P}=0.179$. All studies assessed resting energy expenditure using indirect calorimetry. The study quality assessment also showed no significant effect of body composition method more accurate and reliable method (WMD $4.0295 \% \mathrm{Cl} 0.76,7.28 \mathrm{~kJ} / \mathrm{kg} \mathrm{FFM} /$ day) compared with field method (WMD $12.1495 \% \mathrm{Cl} 3.16,21.11 \mathrm{~kJ} / \mathrm{kg} \mathrm{FFM} /$ day) $\mathrm{P}=0.494$.

\section{DISCUSSION}

This study sought to determine the difference in REE between cancer patients and control subjects through summarizing data available from case-control and pretest/post-test studies. The meta-analysis derived from 16 studies suggested an 8-9\% increase in REE in cancer patients when compared to healthy control groups.

Cancer subtypes were shown in this analysis to generate different degrees of change in REE which is consistent with the previous notion of cancer type and tumour site affecting energy expenditure differently. While all subgroups showed an overall increase the difference was not significant for gastric and colon cancers and varied from $3.86(95 \% \mathrm{Cl} 1.64,6.08) \mathrm{kJ} / \mathrm{kg} \mathrm{FFM} /$ day for Urologic cancers to $22.68(95 \% \mathrm{Cl} 10.80,34.56) \mathrm{kJ} / \mathrm{kg} \mathrm{FFM} /$ day for the single study in liver cancer. Generally the FFM and to a lesser extent the fat mass (FM) are considered the major contributors to the REE. The metabolic activity of the organs however cannot be overlooked for their role in explaining variation in REE particularly if their function is altered by malignancy. Metabolic activity can be defined as the respective processes which occur at a cellular level to enable proper function of an organ. While a high metabolic rate in an organ does not necessarily mean a higher metabolic rate is generated from cancer in that tissue, in some cases metabolic activity has been shown to be elevated in the diseased state with some major organs reportedly being more metabolically demanding than others. The lungs are considered as highly metabolically active organs and can utilise various substrates for normal function[36] which may somewhat explain for the elevations. According to the subgroup analysis (Figure 4) pancreatic cancer was also observed to generate an increase in REE. As the pancreas possesses both endocrine and exocrine functions, it has the potential to influence metabolism through inflammatory processes or the altered use of substrates. It has been suggested the flux of glucose in cancer patients may be elevated suggesting increased glucose demand[37]. Given that incomplete oxidation of glucose is to be replaced by fat oxidation[4] this could result in an increase in energy expenditure of 1050-1260kJ/day[37] which would correspond to approximately $0.9 \mathrm{~kg}$ fat loss $/$ month. This could be a possible explanation for the progressive weight loss often observed in cancer patients. According to the subgroup analysis (Figure 4), REE was also significantly altered in patients with head and neck and oesophageal cancer. Of the 3 studies reviewed, only 1 study was 
included in the analyses. Langius et al[27] reported no significant differences between cancer patients and control participants.

Findings from Silver et al[30] were similar to those reported by Langius et al[27] despite each of the patients in the study population being classified as either Stage 3 or $4 a$ for cancer progression[30]. Garcia-Peris et al[20] ${ }^{2}$ reported slightly higher metabolic rates to those of Langius et al[27] and Silver et al[30]. Interestingly, Garcia-Peris et al[20] observed a declining trend in REE amongst cancer patients during chemoradiotherapy which returned to pre-treatment values post treatment with FFM largely maintained. This strongly suggests REE is unlikely to be considerably altered in head and neck cancer patients and the post-treatment increase in REE was largely due to unchanged FFM[20].

Four studies investigating REE in oesophageal cancer patients were included in this review and analyses. Thomson et al[32] reported unchanged REE among patients with oesophageal cancer whereas the results from three other studies reported elevations[4, 34, 35]. The mean REE reported by Wu et al[35] was much higher than those reported by other authors regarding oesophageal cancer $(240.66 \mathrm{~kJ} / \mathrm{kg} / \mathrm{day}$ FFM) and other cancer types. The extent of this elevation is questionable considering the reported mean REE from WL and WS patients were not elevated to such a degree. However, Wu et al[35] have reported inflammatory responses amongst cancer patients. Similarly, a number of authors[8, 11, 31]studying other cancer types have associated elevated REE with inflammatory cytokines, such as Creactive protein (CRP), interleukins 1 and 6 (IL-1; IL-6) and tumour necrosis factor (TNF). It has been suggested the contribution of humoral factors to hypermetabolism and cancer cachexia may be mediated by these cytokines and promote increased proteolysis, lipolysis and various glucose-synthesising pathways[38, 39]. This theory could be valid and applicable with this clinical population as weight loss in healthy individuals generally does not involve inflammatory processes. Although the subgroup analysis concluded patients with head and neck and oesophageal cancers experience metabolic derangements, it is important to consider the inconsistencies of the studies used in this subgroup. Given that more studies concerning oesophageal cancer were used in the subgroup analysis, this may bias the overall REE for this subgroup and may not accurately reflect metabolic alterations in patients with head and neck cancer.

Only one study included in the analyses looked at REE in cirrhotic patients with hepatocellular carcinoma (HCC) and documented increased REE. Merli et al[5] reported an average increase of $22.68 \mathrm{~kJ} / \mathrm{kg} /$ day FFM with weight-losing patients having higher REE than weight-stable patients. Tumour stage was not considered a major determinant of REE in cirrhotic patients with HCC as elevations in REE was consistently observed amongst patients, and nil correlations between tumour size and REE were made. Similar conclusions have been made in regard to other cancer types studied by other authors[5, 21,32, 33]. However, these conclusions are opposed to findings from Jebb et al[26] who reported a reduction in REE in lung cancer patients when tumour size was reduced, this study used cirrhotic controls which may explain the differences in results. There was only one study included in the meta-analysis (Figure 4) which studied REE in urologic cancer patients. Xu et al[6] observed a significant increase in REE among cancer patients with kidney and adrenal cancers reportedly causing the greatest elevations. A possible explanation for observed elevations among HCC and urologic cancer patients may be due to its 
usual metabolic demands when in a non-diseased state. It has been proposed by Holliday, as discussed by Weinsier et al[40], that large internal organs, such as the liver and kidneys, could produce similar REE to that of skeletal muscle. Additionally, when in a diseased state, the liver serves a role in inflammation and increased energy production via gluconeogenesis which could potentially further elevate $\operatorname{REE}[11,28]$. This may mean that some organs become more metabolically demanding when they are cancerous and this may contribute to the increased metabolic rate. Due to the limited number of studies for both these cancer types, it would be difficult to derive any valid conclusions regarding changes in REE.

Studies investigating gastric and colorectal cancers consistently presented insignificant changes in REE when compared to healthy control groups. Cao et al[ $[4]^{4}$ found elevations in gastric cancer patients but observed unchanged REE in patients with colorectal cancer. Other authors[3, 7, 16, 18, 19, 21, 29] saw insignificant changes. Two studies[3,16] reported unchanged REE among gastric-colorectal cancer patients. However, this could be explained by the authors' use of the same gastric-colorectal cancer patients in both studies. This is important to consider as this factor could also affect the findings of this present study. Two authors[16, 28 $]^{4}$ reported the presence of liver metastasis amongst certain patients with gastric and colorectal cancers with mixed conclusions in relation to REE. Fredrix et a[16] observed nil elevations in REE amongst patients with liver metastasis, whereas Lieffers et al[28] concluded that the presence of metastasis would contribute to elevated REE. Given that metastasis would produce a greater tumour burden, it is valid to believe REE would be further elevated in these patients. However, this review is unable to support this notion due to the small number of included studies which reported the effects of metastasis on REE and its conflicting findings.

Another factor which may affect energy expenditure is gender and whether the patients are weight stable or losing weight. Nixon et al[29] reported elevations in REE, although not statistically significant, only in weight-losing and weight-stable female colon cancer patients whereas male patients experienced slightly lower or unchanged REE when compared to control participants despite no correlations being made between REE and caloric intake. Although a secondary analysis demonstrated there was no difference between weight losing and weight stable patients only 5 studies reported these subgroups. We also investigated the differences in gender however only 2 studies reported results by gender and no differences were found. The dataset as a whole contained a larger proportion of males to females (Table 1). Although it is anticipated much of the gender difference is related to body composition there maybe additional gender specific affects which could not be examined in this analysis.

\section{Limitations and recommendations}

There were a limited number of patients that have been studied in each of the cancer subtypes. Results from this study should, therefore, be interpreted with caution as more data was available for analysis of REE in lung, gastric and colon cancers. Available data for liver pancreatic and head and neck cancers were rather limited, and the derived alterations in REE would lack statistical power. Some studies in this review were published by the same authors who have utilised the same research methodology, and the statistical analyses had several data entries contributed by the same authors. Unique subgroups in these papers were analysed as independent 
samples[15] and the sample size was adjusted to accommodate the use of the same control group[14], Despite this some authors may have used the same subject data in different studies making the total number of independent subjects uncertain..

The majority of studies were published before 2000 with only 6 studies published in the last 5 years, although we investigated this in a secondary analysis and did not see any differences, advances in cancer treatment may have an effect on metabolism. Table 1 also shows differences in the methodology used to assess energy expenditure (although indirect calorimetry using a ventilated hood was the primary method) and body composition methodology. Several studies used field methods to assess body composition reducing the quality of the studies although this did not have an effect on the results using meta regression.

This analysis did not consider several other cancers known to raise REE. Haematological cancers and sarcomas have been reported to raise REE[41, 42] and these findings could serve an insightful addition to the current study. Due to the exclusion criteria used, these and other studies which published findings about other types of cancers not mentioned in this study were unable to be included.

Studies investigating cancer and metabolic rate often measure REE using body weight instead of FFM which resulted in the exclusion of many studies in this analysis. Although FFM is often regarded as a more accurate indicator of REE[9, 10], many studies did not adjust REE for FFM. Furthermore, $40 \%$ of the included studies used the Harris-Benedict equation (HBE) to compare differences in energy expenditure instead of healthy control groups and, therefore, were not used in the analyses. It has been widely acknowledged the HBE tend to underestimate REE in healthy individuals. Daly et al[43] found the use of HBE to predict energy expenditure may not be a valid or reliable approach as it overestimated REE by $10.4 \%$ in healthy individuals, whereas Campbell et al[44] observed underestimations between 9-23\% in critically ill and underweight male patients. Therefore, REE derived from the HBE may not be applicable to be used as a reference for comparison in cancer patients. Therefore, future investigations that measure REE adjusted for FFM and use healthy control groups would be advantageous in contributing to current knowledge regarding the cancer types discussed in this study and also other cancer types known to generate metabolic abnormalities, such as leukaemias.

Cancer cachexia was often discussed by authors as the background for conducting the respective studies. Yet, cachexia was not definitively identified in study patients and patients who experienced a large amount of weight loss ( $>10 \%$ of usual body weight) may have experienced varying degrees of cachexia. As cachexia greatly involves the inflammatory response and altered energy metabolism, REE would subsequently increase. If this was the case, the measured REE of patients who experienced large amounts of weight loss would skew the results reported by the authors and the results of this meta-analysis.

In conclusion, this meta-analysis supports current evidence of elevated REE in cancer patients when compared to healthy control participants with an observed 8$9 \%$ increase. Additionally, this study emphasised the heterogeneity observed among cancer types in REE. Due to the exclusion of many studies, not all cancer types were included in the meta-analysis as the results were not expressed as REE based on FFM. Further investigation of alterations in energy expenditure based on FFM can 
assist to clarify previous findings, in particular for cancer types not included in this review, and to provide renewed data. New data will build the current evidence base for the provision of additional nutrition support to compensate for elevated energy consumption in metastatic cancer patients[14].

\section{FUNDING}

Authors declare no source of funding was provided for this study.

\section{CONFLICT OF INTEREST}

The authors report no conflicts of interest to declare.

\section{REFERENCES}

1. Baumgartner, R.N., S.B. Heymsfield, and A.F. Roche, Human body composition and the epidemiology of chronic disease. Obes Res, 1995. 3(1): p. 73-95.

2. Douglas, R.G. and J.H.F. Shaw, Metabolic effects of cancer. British Journal of Surgery, 1990. 77(3): p. 246-254.

3. Fredrix, E.W., et al., Effect of different tumor types on resting energy expenditure. Cancer Research, 1991. 51(22): p. 6138-6141.

4. $\quad$ Cao, D.X., et al., Resting energy expenditure and body composition in patients with newly detected cancer. Clin Nutr, 2010. 29(1): p. 72-7.

5. Merli, M., et al., Increased energy expenditure in cirrhotic patients with hepatocellular carcinoma. Nutrition (Burbank, Los Angeles County, Calif.), 1992. 8(5): p. 321-325.

6. Xu, W.P., et al., Analysis of energy utilization and body composition in kidney, bladder, and adrenal cancer patients. Urologic Oncology, 2012. 30(5): p. 711-718.

7. Fearon, K.C., et al., Influence of whole body protein turnover rate on resting energy expenditure in patients with cancer. Cancer Res, 1988. 48(9): p. 2590-5.

8. Trutschnigg, B., et al., Metabolic, nutritional and inflammatory characteristics in elderly women with advanced cancer. Journal of Geriatric Oncology, 2013. 4(2): p. 183-189.

9. Nielsen, S., et al., Body composition and resting energy expenditure in humans: role of fat, fat-free mass and extracellular fluid. Int J Obes Relat Metab Disord, 2000. 24(9): p. 1153-7.

10. Nelson, K.M., et al., Prediction of resting energy expenditure from fat-free mass and fat mass. Am J Clin Nutr, 1992. 56(5): p. 848-56.

11. Falconer, J.S., et al., Cytokines, the acute-phase response, and resting energy expenditure in cachectic patients with pancreatic cancer. Ann Surg, 1994. 219(4): p. 325-31.

12. Shike, M., et al., Changes in body composition in patients with small-cell lung cancer. The effect of total parenteral nutrition as an adjunct to chemotherapy. Ann Intern Med, 1984. 101(3): p. 303-9.

13. Harris, R., et al., metan: fixed-and random-effects meta-analysis. Stata Journal, 2008. 8(1): p. 3-28.

14. Higgins, J.P. and S. Green, Cochrane Handbook for systematic reviews of interventions. 2008, Chichester, West Sussex; Hoboken, NJ: Wiley-Blackwell.

15. Borenstein, M., et al., Introduction to Meta-analysis. 2009, Chicester, West Sussex: John Wiley \& Sons Ltd.

16. Fredrix, E.W., et al., Resting energy expenditure in patients with newly detected gastric and colorectal cancers. The American Journal Of Clinical Nutrition, 1991. 53(5): p. 1318-1322.

17. Fredrix, E.W., A.J. Staal-van den Brekel, and E.F. Wouters, Energy balance in nonsmall cell lung carcinoma patients before and after surgical resection of their tumors. Cancer, 1997. 79(4): p. 717-723. 
18. Fredrix, E.W., et al., Resting energy expenditure in patients with non-small cell lung cancer. Cancer, 1991. 68(7): p. 1616-21.

19. Fredrix, E.W.H.M., et al., Energy balance in relation to cancer cachexia. Clinical Nutrition, 1990. 9(6): p. 319-324.

20. Garcia-Peris, P., et al., Prospective study of resting energy expenditure changes in head and neck cancer patients treated with chemoradiotherapy measured by indirect calorimetry. Nutrition, 2005. 21(11-12): p. 1107-12.

21. Hansell, D.T., J.W. Davies, and H.J. Burns, Effects of hepatic metastases on resting energy expenditure in patients with colorectal cancer. Br J Surg, 1986. 73(8): p. 659-62.

22. Hansell, D.T., J.W. Davies, and H.J. Burns, The effects on resting energy expenditure of different tumor types. Cancer, 1986. 58(8): p. 1739-1744.

23. Hansell, D.T., J.W. Davies, and H.J. Burns, The relationship between resting energy expenditure and weight loss in benign and malignant disease. Ann Surg, 1986. 203(3): p. 240-5.

24. Harvie, M.N., et al., Energy balance in patients with advanced NSCLC, metastatic melanoma and metastatic breast cancer receiving chemotherapy--a longitudinal study. Br J Cancer, 2005. 92(4): p. 673-80.

25. Harvie, M.N., et al., Energy balance in early breast cancer patients receiving adjuvant chemotherapy. Breast Cancer Research and Treatment, 2004. 83(3): p. 201-210.

26. Jebb, S.A., et al., Measurements of resting energy expenditure and body composition before and after treatment of small cell lung cancer. Ann Oncol, 1994. 5(10): p. 915-9.

27. Langius, J.A.E., et al., Resting energy expenditure in head and neck cancer patients before and during radiotherapy. Clinical Nutrition, 2012. 31(4): p. 549-554.

28. Lieffers, J.R., et al., A viscerally driven cachexia syndrome in patients with advanced colorectal cancer: contributions of organ and tumor mass to whole-body energy demands. Am J Clin Nutr, 2009. 89(4): p. 1173-9.

29. Nixon, D.W., et al., Resting energy expenditure in lung and colon cancer. Metabolism, 1988. 37(11): p. 1059-64.

30. Silver, H.J., M.S. Dietrich, and B.A. Murphy, Changes in body mass, energy balance, physical function, and inflammatory state in patients with locally advanced head and neck cancer treated with concurrent chemoradiation after low-dose induction chemotherapy. Head and Neck, 2007. 29(10): p. 893-900.

31. Staal-van den Brekel, A.J., et al., Analysis of the energy balance in lung cancer patients. Cancer Research, 1994. 54(24): p. 6430-6433.

32. Thomson, S.R., et al., Resting metabolic rate of esophageal carcinoma patients: a model for energy expenditure measurement in a homogenous cancer population. JPEN J Parenter Enteral Nutr, 1990. 14(2): p. 119-21.

33. Vaisman, N., et al., Effect of tumor load on energy expenditure in patients with pancreatic cancer. Pancreas, 2012. 41(2): p. 230-232.

34. Weston, P.M.T., et al., Diet-induced thermogenesis in patients with gastrointestinal cancer cachexia. Clinical Science, 1989. 77(2): p. 133-138.

35. Wu, J., et al., Weight loss and resting energy expenditure in male patients with newly diagnosed esophageal cancer. Nutrition, 2013. 29(11-12): p. 1310-4.

36. Fisher, A.B., Intermediary metabolism of the lung. Environ Health Perspect, 1984. 55: p. 14958.

37. Eden, E., et al., Glucose flux in relation to energy-expenditure in malnourished patients with and without cancer during periods of fasting and feeding. Cancer Research, 1984. 44(4): p. 1718-1724.

38. Bertazza, L. and S. Mocellin, The dual role of tumor necrosis factor (TNF) in cancer biology. Curr Med Chem, 2010. 17(29): p. 3337-3352. 
39. Argiles, J.M. and F.J. Lopez-Soriano, The role of cytokines in cancer cachexia. Med Res Rev, 1999. 19(3): p. 223-48.

40. Weinsier, R.L., Y. Schutz, and D. Bracco, Reexamination of the relationship of resting metabolic rate to fat-free mass and to the metabolically active components of fat-free mass in humans. Am J Clin Nutr, 1992. 55(4): p. 790-4.

41. Shaw, J.H.F., D.M. Humberstone, and R.R. Wolfe, Energy and protein-metabolism in sarcoma patients. Annals of Surgery, 1988. 207(3): p. 283-289.

42. Humberstone, D.A. and J.H.F. Shaw, Metabolism in hematologic malignancy. Cancer, 1988. 62(8): p. 1619-1624.

43. Daly, J.M., et al., Human energy requirements: overestimation by widely used prediction equation. Am J Clin Nutr, 1985. 42(6): p. 1170-4.

44. Campbell, C.G., E. Zander, and W. Thorland, Predicted vs measured energy expenditure in critically ill, underweight patients. Nutr Clin Pract, 2005. 20(2): p. 276-80. 
Table 1. Characteristics of studies investigating the alterations in REE per kg FFM in cancer patients.

\begin{tabular}{|c|c|c|c|c|c|}
\hline Source & $\begin{array}{c}\text { Study sample number, } M / F, \text { Mean } \\
\text { age }\end{array}$ & $\begin{array}{l}\text { Control sample number, } \\
M / F \text {, Mean age }\end{array}$ & Study design & Methodology used to measure REE \& FFM & Subjective study summary \\
\hline Cao et al. $2010^{4}$ & $\begin{array}{l}714 \text { newly detected cancer } \\
\text { patients. } \\
150 \text { oesophageal, } 154 \text { gastric, } \\
148 \text { colorectal, } 128 \text { pancreatic, } \\
134 \text { NSCLC } \\
M / F=477 / 237 \text {, Age } 56\end{array}$ & $\begin{array}{l}642 \text { control subjects } \\
M / F=445 / 195 \\
\text { Age } 55.4\end{array}$ & $\begin{array}{l}\text { Case control. } \\
\text { Cancer patients \& control participants } \\
\text { recruited from hospital setting. Cancer } \\
\text { patients were adults, afebrile, nil organ } \\
\text { dysfunction, nil cancer treatment, nil } \\
\text { endocrine abnormalities, nil dialysis/fluid } \\
\text { replacement. }\end{array}$ & $\begin{array}{l}\text { REE measured via IC using ventilated hood system } \\
\text { in standard resting conditions ( }>3 \text { hours } \\
\text { postprandial, } 30 \text { minute bed rest). } \\
\text { FFM determined using formula ( } 1.106 x E C F+1.521 x \\
\text { ICF). ECF, ICF \& total water determined using } \\
\text { multi-BIA. } \\
\text { FM determined using formula (BW-FFM). }\end{array}$ & $\begin{array}{l}\text { Cancer patients (all subgroups) had } \\
\text { higher REE than controls. WL cancer } \\
\text { patients had higher REE than WS and } \\
\text { control patients. Stage IV patients had } \\
\text { higher REE than Stages I-III. Cancer } \\
\text { type, pathological stage, duration of } \\
\text { disease responsible for REE. }\end{array}$ \\
\hline $\begin{array}{l}\text { Falconer et al. } \\
1994^{11}\end{array}$ & $\begin{array}{l}21 \text { pancreatic cancer patients. } \\
M / F=14 / 7 \\
\text { Age } 57\end{array}$ & $\begin{array}{l}16 \text { control subjects } \\
M / F=11 / 5 \\
\text { Age } 55\end{array}$ & $\begin{array}{l}\text { Case control. } \\
\text { Patients with newly detected tumours. Cancer } \\
\text { patients received nil treatment, afebrile, nil } \\
\text { infection, nil cholangitis one month prior, nil } \\
\text { jaundice. Patients had stage } 2(n=7) \text {, stage } 3 \\
(n=8) \& \text { stage } 4(n=6) \text { using Union } \\
\text { Internationale Contre le Cancer TNM } \\
\text { classification. } \\
\text { Control participants admitted for minor } \\
\text { elective surgical procedures. }\end{array}$ & $\begin{array}{l}\text { REE via IC using a ventilated hood system after } \\
\text { overnight fast in resting conditions. } \\
\text { FFM measured via BIA. }\end{array}$ & $\begin{array}{l}\text { Pancreatic cancer patients had higher } \\
\text { REE than controls. }\end{array}$ \\
\hline $\begin{array}{l}\text { Fearon et al. } \\
1988^{7}\end{array}$ & $\begin{array}{l}20 \text { lung cancer patients. } \\
M / F=- \text {, Age } 60 \\
38 \text { colon cancer patients } \\
M / F=-, \text { Age } 64.5\end{array}$ & $\begin{array}{l}22 \text { control subjects (non- } \\
\text { neoplastic diseases). } \\
M / F=-, \text { Age } 58.8\end{array}$ & $\begin{array}{l}\text { Case control. } \\
\text { Lung cancer patients with nil previous } \\
\text { treatment two months prior. Stage } 2(n=9) \& \\
\text { stage } 3(n=11) \text { using WHO classification. } \\
\text { Colon cancer patients studied prior to } \\
\text { laparotomy. Stage } B(n=16) \text {, stage } C(n=11) \text {, } \\
\text { stage } D(n=10) \text { using Dukes' classification. } \\
\text { Control participants had non-neoplastic } \\
\text { disease. }\end{array}$ & $\begin{array}{l}\text { REE via IC with a rigid canopy (sensitive } \\
\text { paramagnetic oxygen analyser) \& an IR carbon } \\
\text { dioxide analyser. Patients were fasted overnight \& } \\
\text { at rest for } 30 \text { minutes. } \\
\text { FFM derived from measurements of total body } \\
\text { water. }\end{array}$ & $\begin{array}{l}\text { Nil significant difference in REE } \\
\text { between both cancer groups and } \\
\text { controls. }\end{array}$ \\
\hline
\end{tabular}




\begin{tabular}{|c|c|c|c|c|c|}
\hline $\begin{array}{l}\text { Fredrix et al. } \\
1991^{34}\end{array}$ & $\begin{array}{l}104 \text { gastric/colorectal patients } \\
\text { (25/104 had liver metastases; } \\
41 / 104 \text { had stages } 1 \text { and } 2 ; 63 / 104 \\
\text { had stages } 3 \& 4 \text { ). } \\
M / F=54 / 50, \text { Age } 70\end{array}$ & $\begin{array}{l}72 \text { control subjects } \\
32 \mathrm{GI} \text { diseases } \\
\mathrm{M} / \mathrm{F} \mathrm{GI}=20 / 12 \text {, Age } 64 \\
40 \text { healthy } \\
\mathrm{M} / \mathrm{F}=18 / 22 \text { Age } 65\end{array}$ & $\begin{array}{l}\text { Case control. } \\
\text { Patients with newly detected cancer \& nil } \\
\text { previous treatment. } \\
\text { Control participants with non-malignant GI } \\
\text { diseases. }\end{array}$ & $\begin{array}{l}\text { REE calculated using abbreviated Weir formula. } \\
\text { Ventilated hood system used to measure gas } \\
\text { exchange. Cancer patients were fasted overnight } 7 \\
\text { after }>30 \text { minute bed rest. REEs of cancer patients } \\
\& \text { some control participants measured during } \\
\text { hospital stay. REE of remaining control participants } \\
\text { measured on an outpatient basis. } \\
\text { FFM estimated using BIA \& calculated using } \\
\text { formula of Segal. }\end{array}$ & $\begin{array}{l}\text { REE not elevated in GCR- cancer } \\
\text { patients compared to controls. } \\
\text { Nil association between increasedREE } \\
\text { and cancer stage. }\end{array}$ \\
\hline $\begin{array}{l}\text { Fredrix et al. } \\
1997^{35}\end{array}$ & $\begin{array}{l}53 \text { NSCLC patients (pre-surgery); } 39 \\
\text { patients (post-surgery) } \\
M / F \text { no recurrence }=20 / 10 \\
M / F \text { tumour recurrence }=8 / 1 . \text { Age } \\
65.5\end{array}$ & $\begin{array}{l}\text { NSCLC patients acted as } \\
\text { their own controls }\end{array}$ & $\begin{array}{l}\text { Pre-test/Post-test. } \\
\text { Cancer patients had newly detected primary } \\
\text { NSCLC. Nil previous treatment, afebrile, nil } \\
\text { high doses of steroids, nil severe endocrine } \\
\text { abnormalities. }\end{array}$ & $\begin{array}{l}\text { REE measured by IC using ventilated hood system } \\
\text { after overnight fast \& were rested for }>20 \text { minutes. } \\
\text { Post resection REE measured on an outpatient } \\
\text { basis. REE calculated using abbreviated Weir } \\
\text { formula. } \\
\text { FFM estimate using BIA. FFM = total body } \\
\text { water/0.73. } \\
\text { REE measured prior to patients undergoing } \\
\text { surgery. REE also measured } 3,6 \& 12 \text { months post } \\
\text { resection. }\end{array}$ & $\begin{array}{l}\text { REE reduced slightly after surgery in } \\
\text { hyper-metabolic patients. }\end{array}$ \\
\hline $\begin{array}{l}\text { Fredrix et al. } \\
1991^{36}\end{array}$ & $\begin{array}{l}30 \text { NSCLC patients } \\
M / F=27 / 3 \text {, Age } 65 \\
104 \text { gastric/colorectal patients } \\
M / F=54 / 50, \text { Age } 70\end{array}$ & $\mathrm{Nil}$ & $\begin{array}{l}\text { Post-test. } \\
\text { Cancer patients had newly detected NSCLC \& } \\
\text { had nil previous treatment. }\end{array}$ & $\begin{array}{l}\text { REE measured by IC using ventilated hood system } \\
\text { after overnight fast \& } 30 \text { minute rest period. REE } \\
\text { calculated using abbreviated Weir formula. } \\
\text { FFM estimated using BIA \& calculated using } \\
\text { formula of Segal. }\end{array}$ & $\begin{array}{l}\text { REE elevated in lung cancer patients. } \\
\text { Strong correlation between increased } \\
\text { REE and weight loss in lung cancer } \\
\text { patients. }\end{array}$ \\
\hline
\end{tabular}




\begin{tabular}{|c|c|c|c|c|c|}
\hline $\begin{array}{l}\text { Fredrix et al. } \\
1990^{37}\end{array}$ & $\begin{array}{l}39 \\
22 \mathrm{GCR} \text { patients } \\
\mathrm{M} / \mathrm{F}=13 / 9, \text { Age } 68 \\
17 \text { lung patients } \\
\mathrm{M} / \mathrm{F}=16 / 1, \text { Age } 68\end{array}$ & $\begin{array}{l}40 \text { healthy controls } \\
\mathrm{M} / \mathrm{F}=18 / 22 \\
\text { Age } 65\end{array}$ & $\begin{array}{l}\text { Case control. } \\
\text { Cancer patients had newly detected tumours } \\
\text { \& had nil previous treatment. } \\
\text { Control participants were healthy. Nil health } \\
\text { conditions reported. }\end{array}$ & $\begin{array}{l}\text { REE measured via IC using ventilated hood system } \\
\text { after overnight fast \& rested for }>30 \text { minutes. } \\
\text { BIA used to measure body composition. FFM } \\
\text { estimated using formula of Segal. }\end{array}$ & $\begin{array}{l}\text { REE elevated in lung cancer patients. } \\
\text { Tumour type affects REE. Reduced et in } \\
\text { GCR patients explained weight loss as } \\
\text { REE is unchanged. Increased REE and } \\
\text { low El explained weight loss. }\end{array}$ \\
\hline $\begin{array}{l}\text { Garcia-Peris et } \\
\text { al. } 2005^{22}\end{array}$ & $\begin{array}{l}18 \mathrm{H} \& \mathrm{~N} \text { patients (stages } 3 \& 4 \text { ) } \\
\mathrm{M} / \mathrm{F}=15 / 3 \text {, Age } 57\end{array}$ & Nil & $\begin{array}{l}\text { Pre-test/post-test. } \\
\text { H\&N cancer patients (stage } 3 \& 4 \text { ) without } \\
\text { distant metastasis. Nine patients had previous } \\
\text { radical surgery. All patients treated with } \\
\text { radiotherapy \& concurrent chemotherapy. }\end{array}$ & $\begin{array}{l}\text { REE measured via IC (open circuit calorimeter) } \\
\text { after overnight fast. REE calculated using Weir } \\
\text { formula. } \\
\text { Tetrapolar, single frequency Holtain BC analyser } \\
\text { (BIA) to measure body composition. FFM } \\
\text { calculated using software provided by } \\
\text { manufacturer. } \\
\text { REE \& FFM measured before treatment, at weeks } \\
\text { 2, } 4 \text { \& 6, and } 2 \text { weeks post treatment. }\end{array}$ & $\begin{array}{l}\text { REE decreases during chemotherapy } \\
\text { but normalises at the end of treatment. } \\
\text { Effects of treatment may contribute to } \\
\text { reduced REE. FFM increased which may } \\
\text { explain increased REE and weight loss. }\end{array}$ \\
\hline $\begin{array}{l}\text { Hansell et al. } \\
1986^{38}\end{array}$ & $\begin{array}{l}24 \text { colon } \\
\text { Tumour-bearing } \\
M / F=5 / 4 \text {, Age } 68 \\
\text { Tumour-free } \\
M / F=8 / 7 \text {, Age } 65\end{array}$ & $\begin{array}{l}\text { Each patient acted as } \\
\text { his/her own control }\end{array}$ & $\begin{array}{l}\text { Pre-test/post-test. } \\
\text { Cancer patients had nil infection, nil } \\
\text { treatment. } \\
\text { Tumour-bearing patients had hepatic } \\
\text { metastasis. Tumour-free patients showed nil } \\
\text { hepatic metastasis. }\end{array}$ & $\begin{array}{l}\text { REE measured using IC with rigid canopy after } \\
\text { overnight fast \& } 30 \text { minute rest period. REE } \\
\text { calculated using Weir's formula. } \\
\text { FFM derived from measurement of total body } \\
\text { water assuming lean tissue contains } 73 \% \text { water } \\
\text { (urine collected } 3 \& 4 \text { hours after tritium } \\
\text { injections). } \\
\text { REE \& FFM measured pre-operatively and post- } \\
\text { operatively. }\end{array}$ & $\begin{array}{l}\text { REE between tumour-free and tumour- } \\
\text { bearing patients showed nil significant } \\
\text { difference. Colon cancer had nil effect } \\
\text { on REE. }\end{array}$ \\
\hline $\begin{array}{l}\text { Hansell et al. } \\
1986^{14}\end{array}$ & $\begin{array}{l}84 \text { patients } \\
51 \text { colorectal } \\
M / F=29 / 22, \text { Age } 67 \\
22 \text { gastric } \\
M / F=14 / 8 \text {, Age } 67 \\
11 \text { bronchial } \\
M / F=9 / 2 \text {, Age } 61\end{array}$ & Nil & $\begin{array}{l}\text { Case series. } \\
\text { Cancer patients had nil infection, nil } \\
\text { treatment. }\end{array}$ & $\begin{array}{l}\text { REE measured via IC with rigid canopy after } \\
\text { overnight fast \& after } 30 \text { minute rest period. REE } \\
\text { calculated using Weir formula. } \\
\text { FFM derived from measurement of total body } \\
\text { water assuming lean tissue contains } 73 \% \text { water } \\
\text { (urine collected } 3 \text { \& } 4 \text { hours after tritium } \\
\text { injections). }\end{array}$ & $\begin{array}{l}\text { Nil significant difference in REE } \\
\text { between cancer groups. }\end{array}$ \\
\hline
\end{tabular}




\begin{tabular}{|c|c|c|c|c|c|}
\hline $\begin{array}{l}\text { Hansell et al. } \\
1986^{39}\end{array}$ & $\begin{array}{l}98 \text { patients } \\
\text { (91 GCR \& } 7 \text { bronchial) } \\
56 \text { WS } \\
M / F=40 / 16, \text { Age } 66 \\
42 W L \\
M / F=23 / 19, \text { Age } 65\end{array}$ & $\begin{array}{l}38 \text { control patients } \\
22 \mathrm{WS} \\
\mathrm{M} / \mathrm{F}=6 / 16 \text {, Age } 62 \\
16 \mathrm{WL} \\
\mathrm{M} / \mathrm{F}=8 / 8, \text { Age } 63\end{array}$ & $\begin{array}{l}\text { Case control. } \\
\text { Cancer patients had nil infection \& nil prior } \\
\text { treatments. } \\
\text { Control patients had non-malignant diseases } \\
\text { (peptic ulcerations, choleithiasis, others). } \\
\text { Liver metastasis present in } 11 \text { WS patients \& } 8 \\
\text { WL patients. }\end{array}$ & $\begin{array}{l}\text { REE measured via IC with rigid canopy after } \\
\text { overnight fast \& after } 30 \text { minute rest period. REE } \\
\text { calculated using Weir formula. } \\
\text { FFM derived from measurement of total body } \\
\text { water assuming lean tissue contains } 73 \% \text { water } \\
\text { (urine collected } 3 \& 4 \text { hours after tritium } \\
\text { injections). }\end{array}$ & $\begin{array}{l}\text { Nil significant difference in REE } \\
\text { between cancer patients and controks. } \\
\text { Tumour type had no influence on } \\
\text { Patients' metabolic response to non- } \\
\text { malignant illness may determine } \\
\text { changes in REE. }\end{array}$ \\
\hline $\begin{array}{l}\text { Harvie et al. } \\
2005^{40}\end{array}$ & $\begin{array}{l}41 \text { patients } \\
19 \text { NSCLC (Stage } 3 \text { or } 4 \text { ) } \\
M / F=15 / 4 \text {, Age } 59 \\
12 \text { metastatic melanoma } \\
M / F=9 / 3, \text { Age } 54 \\
10 \text { metastatic breast } \\
M / F=0 / 10 \text {, Age } 56\end{array}$ & $\begin{array}{l}\text { Healthy control } \\
\text { participants also recruited. } \\
\text { Number of participants } \\
\text { not reported \& only REE } \\
\text { measured in this group. }\end{array}$ & $\begin{array}{l}\text { Pre-test/Post test. } \\
\text { Cancer patients received nil treatment within } \\
\text { previous } 3 \text { months. } \\
\text { Control participants recruited by hospital staff. }\end{array}$ & $\begin{array}{l}\text { REE via IC under standardised conditions. REE also } \\
\text { measured in control participants but not reported. } \\
\text { FFM determined using total body potassium } \\
\text { (NE8108 shadow shield whole body monitor). } \\
\text { Patients seen prior to commencing chemotherapy, } \\
\text { prior to } 2^{\text {nd }} \text { chemotherapy cycle \& } 1 \text { month post } \\
\text { completion of chemotherapy. }\end{array}$ & $\begin{array}{l}\text { REE elevated in NSCLC patients and } \\
\text { normal in breast cancer and melanoma } \\
\text { patients. }\end{array}$ \\
\hline $\begin{array}{l}\text { Jebb et al. } \\
1994^{42}\end{array}$ & $\begin{array}{l}28 \text { small cell lung cancer } \\
18 \text { responders } \\
M / F=12 / 6, \text { Age } 63 \\
10 \text { non-responders } \\
M / F=8 / 2 \text {, Age } 60\end{array}$ & Nil & $\begin{array}{l}\text { Pre-test/post-test. } \\
\text { SCLC patients recruited over a } 12 \text { month } \\
\text { period in outpatient clinics. Patients received } \\
\text { nil prior treatment. }\end{array}$ & $\begin{array}{l}\text { REE measured using portable IC after overnight } \\
\text { past \& } 30 \text { minute rest period. REE calculated using } \\
\text { equation of Elia \& Livesey. } \\
\text { FFM determined using LUNAR-DPX scanner. } \\
\text { REE \& body composition measured at baseline \& } 1 \\
\text { month post-treatment. }\end{array}$ & $\begin{array}{l}\text { Reduction in tumour mass resulted in } \\
\text { reductions in REE independent of body } \\
\text { composition. Tumours have the ability } \\
\text { to increase REE. }\end{array}$ \\
\hline
\end{tabular}




\begin{tabular}{|c|c|c|c|c|c|}
\hline $\begin{array}{l}\text { Langius et al. } \\
2012^{20}\end{array}$ & $\begin{array}{l}71 \mathrm{H} \& \mathrm{~N} \text { cancer patients } \\
\mathrm{M} / \mathrm{F}=45 / 26 \text {, Age } 65\end{array}$ & $\begin{array}{l}40 \text { healthy controls } \\
M / F=20 / 20, \text { Age } 59\end{array}$ & $\begin{array}{l}\text { Pre-test/post-test, observational. } \\
\text { Cancer patients receiving primary or } \\
\text { postoperative radiotherapy. } \\
\text { Nil patients with distant metastasis, } \\
\text { thyroid/inflammatory diseases, receiving } \\
\text { concurrent chemotherapy or receiving } 2^{\text {nd }} \\
\text { dose of radiotherapy. } \\
\text { Healthy control participants recruited through } \\
\text { advertisement on internet \& in } \\
\text { hospital/university campus. }\end{array}$ & $\begin{array}{l}\text { REE measured via IC prior to treatment, after } 3 \\
\text { weeks of treatment, at the end of treatment, and } \\
12 \text { weeks after completion of treatment. Patients } \\
\text { \& participants were at complete rest for } 30 \\
\text { minutes \& REE calculated using Weir equation. } \\
\text { FFM assessed using single-frequency BIA. FFM } \\
\text { calculated using validated equation of Kyle. } \\
\text { REE of cancer patients pre-treatment was } \\
\text { compared to REE of control participants. }\end{array}$ & $\begin{array}{l}\text { REE didn't differ to controls before } \\
\text { treatment but decreased during apdy } \\
\text { after treatment. }\end{array}$ \\
\hline $\begin{array}{l}\text { Lieffers et al. } \\
2009^{29}\end{array}$ & $\begin{array}{l}18 \text { colorectal cancer patients } \\
\text { Age } 60\end{array}$ & Nil & $\begin{array}{l}\text { Case series. } \\
\text { Cancer patients recruited from the Cross } \\
\text { Cancer Institute (Canada). }\end{array}$ & $\begin{array}{l}\text { REE via IC (after } 12 \text { hour fast } \& 30 \text { minute rest } \\
\text { period. REE calculated using Weir equation. } \\
\text { FFM measured via dual } x \text {-ray absorptiometry scan. }\end{array}$ & $\begin{array}{l}\text { Metastatic disease and organomegaly } \\
\text { can elevate REE. } \\
\text { Variances in REE depend on types of } \\
\text { FFM (i.e. major organs vs. skeletal } \\
\text { muscle). }\end{array}$ \\
\hline $\begin{array}{l}\text { Merli et al. } \\
1992^{5}\end{array}$ & $\begin{array}{l}12 \text { cirrhotic patients with } \mathrm{HCC} \\
M / F=6 / 6 \text {, Age } 64\end{array}$ & $\begin{array}{l}12 \text { cirrhotic patients } \\
\text { without } \mathrm{HCC} \\
M / F=6 / 6 \text {, Age } 55\end{array}$ & $\begin{array}{l}\text { Case control. } \\
\text { Cancer patients had nil prior treatment. } \\
\text { Control patients without HCC selected based } \\
\text { on similar body weight \& height to cancer } \\
\text { patients. }\end{array}$ & $\begin{array}{l}\text { REE measured using a metabolic-measurement } \\
\text { cart with a canopy system after overnight fast \& } 30 \\
\text { minute rest period. } \\
\text { FFM calculated using the method of Durnin \& } \\
\text { Womersley via skin fold tests (biceps, tricepts, } \\
\text { suprailiac \& subscapular). }\end{array}$ & $\begin{array}{l}\text { REE increased in cirrhotic patients with } \\
\text { HCC. Tumour stage not determinant of } \\
\text { REE. }\end{array}$ \\
\hline $\begin{array}{l}\text { Nixon et al. } \\
1988^{16}\end{array}$ & $\begin{array}{l}98 \text { patients } \\
46 \text { colon } \\
\mathrm{M} / \mathrm{F}=30 / 15 \text {, Age } 58.5 \\
52 \mathrm{NSCLC} \\
\mathrm{M} / \mathrm{F}=27 / 11 \text {, Age } 57.5\end{array}$ & $\begin{array}{l}104 \text { controls, } 60 \text { healthy } \\
M / F=17 / 43, \text { Age } \geq 40 \\
5 \text { anorexia nervosa } \\
9 \text { non-neoplastic } G 1 \\
\text { disorders } \\
12 \text { protein-energy } \\
\text { malnutrition } \\
9 \text { chronic lung disease }\end{array}$ & $\begin{array}{l}\text { Case control. } \\
\text { Cancer patients admitted to Emory Clinical } \\
\text { Research Facility or the Emory Oncology } \\
\text { Ward. Patients had nil surgery >21 days prior, } \\
\text { nil acute/chronic diseases, nil } \\
\text { alcohol/tranquiliser abuse. } \\
\text { Control participants divided into } 5 \text { groups. }\end{array}$ & $\begin{array}{l}\text { REE measured using direct gradient-layer whole- } \\
\text { body calorimetry after overnight fast \& } 15 \text { minute } \\
\text { rest period. Chemotherapy patients studied prior } \\
\text { to commencing chemotherapy cycle. } \\
\text { FFM derived from body weight \& skin fold } \\
\text { measurements. FFM calculated using Durnin \& } \\
\text { Womersley method. }\end{array}$ & $\begin{array}{l}\text { REE didn't differ between cancer types } \\
\text { and controls. } \\
\text { REE elevated in WL female lung \& colon } \\
\text { cancer patients. } \\
\text { REE generally higher in WL cancer } \\
\text { patients. }\end{array}$ \\
\hline
\end{tabular}


Nguyen

\begin{tabular}{|c|c|c|c|c|c|}
\hline $\begin{array}{l}\text { Silver et al. } \\
2007^{21}\end{array}$ & $\begin{array}{l}17 \text { Stage III \& IVa H\&N cancer } \\
\text { patients } \\
M / F=15 / 2 \text {, Age } 59\end{array}$ & Nil & $\begin{array}{l}\text { Pre-test/post-test. } \\
\text { Cancer patients recruited from the Vanderbilt- } \\
\text { Ingram Cancer Center. Patients studied prior } \\
\text { to commencing radiotherapy \& } 1 \text { month post } \\
\text { treatment. }\end{array}$ & $\begin{array}{l}\text { REE via IC with open-circuit system after an 8-hour } \\
\text { fast \& } 60 \text { minute rest period. } \\
\text { FFM assessed using dual-energy x-ray } \\
\text { absorptiometry. }\end{array}$ & $\begin{array}{l}\text { Elevated REE } 1 \text { month post } \\
\text { chemoradiation. }\end{array}$ \\
\hline $\begin{array}{l}\text { Staal-van den } \\
\text { Brekel et al. } \\
1994^{17}\end{array}$ & $\begin{array}{l}100 \text { lung patients } \\
M / F=82 / 18, \text { Age } 65\end{array}$ & Nil & $\begin{array}{l}\text { Case series. } \\
\text { Cancer patients had nil previous treatment, nil } \\
\text { steroid treatment, nil severe endocrine } \\
\text { abnormalities, afebrile. }\end{array}$ & $\begin{array}{l}\text { REE measured by IC using ventilated hood system } \\
\text { after an overnight fast at complete rest. } \\
\text { FFM assessed using single frequency BIA \& } \\
\text { calculated using patient specific regression } \\
\text { equation (FFM }=8.9+0.5 \times\left[\text { height }^{2} / \text { resistance]). }\right.\end{array}$ & $\begin{array}{l}\text { Central tumour localisation and } \\
\text { inflammation contribute to increased } \\
\text { REE. WL due to increased REE and } \\
\text { decreased intake. Higher REE in WL } \\
\text { patients. }\end{array}$ \\
\hline $\begin{array}{l}\text { Thomson et al. } \\
1990^{23}\end{array}$ & $\begin{array}{l}14 \text { patients with oesophageal } \\
\text { cancer } \\
M / F=9 / 5 \text {, Age } 54.5\end{array}$ & $\begin{array}{l}17 \text { controls (benign } \\
\text { disease) } M / F=11 / 6 \\
\text { Age } 56\end{array}$ & $\begin{array}{l}\text { Case control. } \\
\text { Cancer patients admitted to King Edward the } \\
\text { VIII Hospital. Patients were studied prior to } \\
\text { surgery. } \\
\text { Control participants admitted for minor } \\
\text { procedures. }\end{array}$ & $\begin{array}{l}\text { REE via IC after overnight fast \& calculated using } \\
\text { modified equations from other authors. } \\
\text { FFM derived from skin fold thickness using the } \\
\text { tables from Durnin \& Womersley. }\end{array}$ & $\begin{array}{l}\text { Tumour had little effect on REE. } \\
\text { Changes in REE were secondary to } \\
\text { changes in body composition. }\end{array}$ \\
\hline $\begin{array}{l}\text { Vaisman et al. } \\
2012^{18}\end{array}$ & $\begin{array}{l}45 \text { pancreatic cancer patients (15 } \\
\text { post-operative; } 30 \text { advanced) } \\
M / F=-, \text { Age } 57\end{array}$ & $\begin{array}{l}75 \text { healthy controls } \\
\text { Age } 57\end{array}$ & Case control, cross sectional study. & $\begin{array}{l}\text { REE measured by IC after overnight fast and } 20 \\
\text { minute rest period. } \\
\text { FFM measured via dual-energy } x \text {-ray } \\
\text { absorptiometry. }\end{array}$ & $\begin{array}{l}\text { REE not significantly different between } \\
\text { groups. Resection of tumour does not } \\
\text { influence REE. }\end{array}$ \\
\hline
\end{tabular}




\begin{tabular}{|c|c|c|c|c|c|}
\hline $\begin{array}{l}\text { Weston et al. } \\
1989^{24}\end{array}$ & $\begin{array}{l}30 \text { cancer patients (gastro- } \\
\text { oesophageal, colorectal, other GI } \\
\text { cancer). } \\
M / F \text { WS }=15 / 5 \text {, Age } 64 \\
M / F W L=5 / 5, \text { Age } 71\end{array}$ & $\begin{array}{l}7 \text { benign controls } \\
\mathrm{M} / \mathrm{F}=3 / 4 \\
\text { Age } 66\end{array}$ & $\begin{array}{l}\text { Case control. } \\
\text { Cancer \& control patients studied prior to } \\
\text { surgery. } \\
\text { Control patients had non-malignant } \\
\text { gastrointestinal disease. }\end{array}$ & $\begin{array}{l}\text { REE via IC after an } 8 \text { hour overnight fast \& } \\
\text { calculated using Weir formula. } \\
\text { FFM derived from total body potassium \& } \\
\text { calculated using values derived by other authors. }\end{array}$ & $\begin{array}{l}\text { WL patients had higher REE but nil } \\
\text { significant difference in REE betwgeg } \\
\text { groups. GI cancer patients have ntt } \\
\text { changes in REE. }\end{array}$ \\
\hline Wu et al. $2013^{25}$ & $\begin{array}{l}56 \text { male oesophageal cancer } \\
\text { patients } \\
M / F=56 / 0 \text {, Age } 61\end{array}$ & $\begin{array}{l}30 \text { healthy controls } \\
\text { Age } 62\end{array}$ & $\begin{array}{l}\text { Case control. } \\
\text { Cancer patients recruited from Xin Hua } \\
\text { Hospital. Patients had nil previous treatment, } \\
\text { afebrile, nil severe endocrine abnormalities, } \\
\text { nil dialysis/fluid replacement. }\end{array}$ & $\begin{array}{l}\text { REE measured via open-circuit IC via ventilated } \\
\text { hood system } 3 \text { hours post-prandial and } 30 \text { minute } \\
\text { bed rest. REE calculated using Weir equation. } \\
\text { FFM determined using four-lead BIA. }\end{array}$ & $\begin{array}{l}\text { REE of cancer patients significantly } \\
\text { increased compared to controls. }\end{array}$ \\
\hline Xu et al. $2012^{6}$ & $\begin{array}{l}122 \text { urologic cancer patients } \\
74 \text { kidney, } 31 \text { bladder, } 17 \text { adrenal } \\
M / F=72 / 50 \text {, Age } 55\end{array}$ & $\begin{array}{l}131 \text { non malignant } \\
\text { controls } \\
M / F=75 / 56 \text {, Age } 54\end{array}$ & $\begin{array}{l}\text { Case control. } \\
\text { Cancer patients \& control participants } \\
\text { recruited from Zhongshan Hosptial, Fudan } \\
\text { University at time of primary diagnoses. }\end{array}$ & $\begin{array}{l}\text { REE via IC using ventilated hood system \& } \\
\text { calculated using equation: } \mathrm{mREE}=5.50 \times \mathrm{VO}_{2} \\
+1.76 \times \mathrm{xCO}_{2} \\
\text { FFM determined using multi-BIA from ICF \& ECF, } \\
\text { using equation: } \mathrm{FFM}=1.106 \mathrm{xECF}+1.521 \times \mathrm{XCF} \text {. } \\
\text { REE \& FFM measured pre-operatively. }\end{array}$ & $\begin{array}{l}\text { REE significantly elevated in cancer } \\
\text { patients. REE can be influenced by } \\
\text { tumour type and tumour stage. }\end{array}$ \\
\hline
\end{tabular}

REE, resting energy expenditure; FFM, fat free mass; NSCLC, non small cell lung carcinoma; M, male; F, female; -, gender distribution unspecified; WS, weight stable; WL, weight loss; GCR, gastric-colorectal; EI,

energy intake; H\&N, head \& neck; HCC, hepatocellular carcinoma; IC, indirect calorimetry; BIA, bioelectrical impedance analysis. 


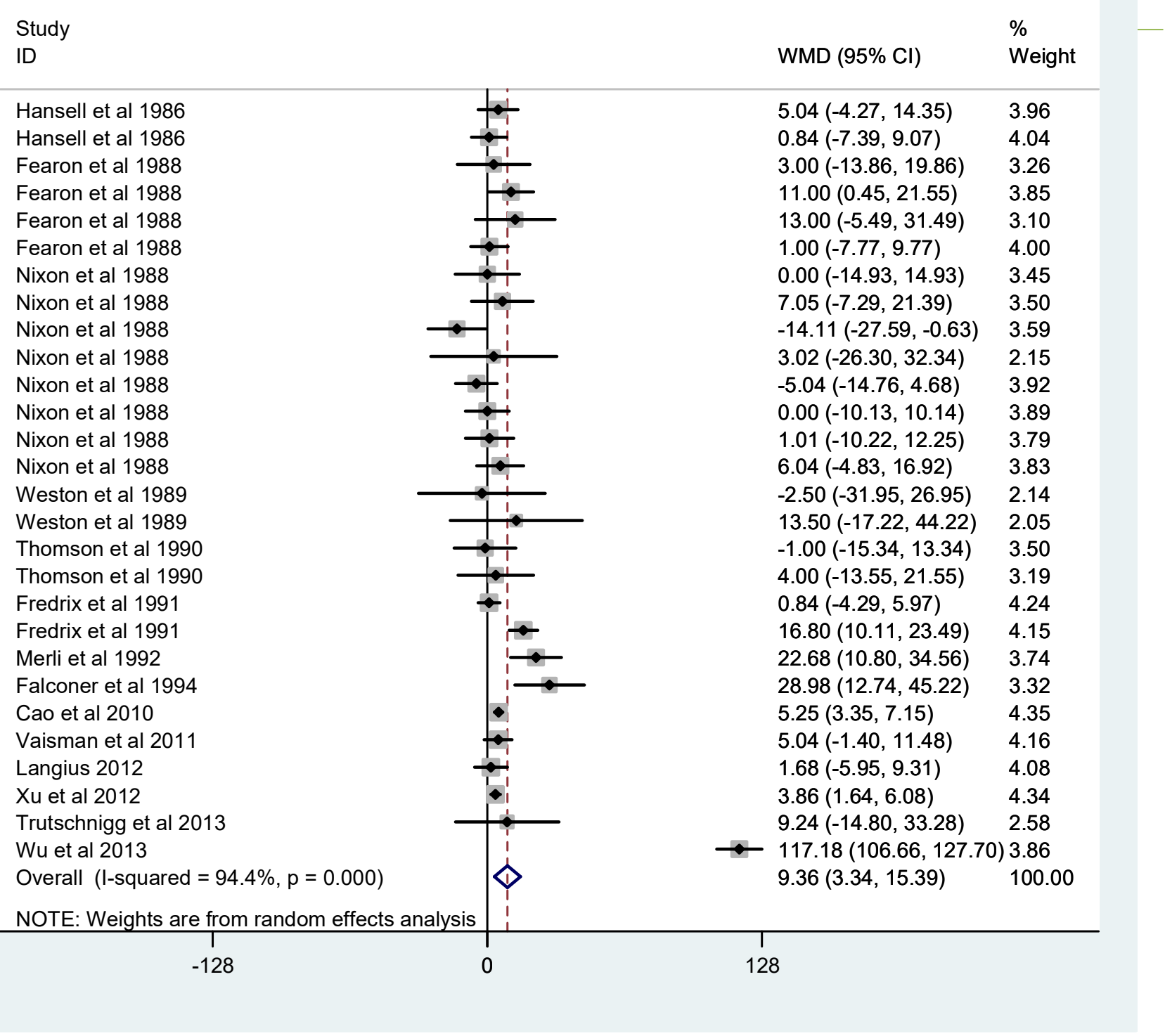

Figure 1. Mean REE/FFM is significantly higher in cancer patients. The size of the shaded squares is proportional to the weight of each study. The horizontal lines represent $95 \% \mathrm{Cl}$. Multiple entries from the same paper represent figures presented divided by cancer subtype, weight losing/weight stable and/or sex. 


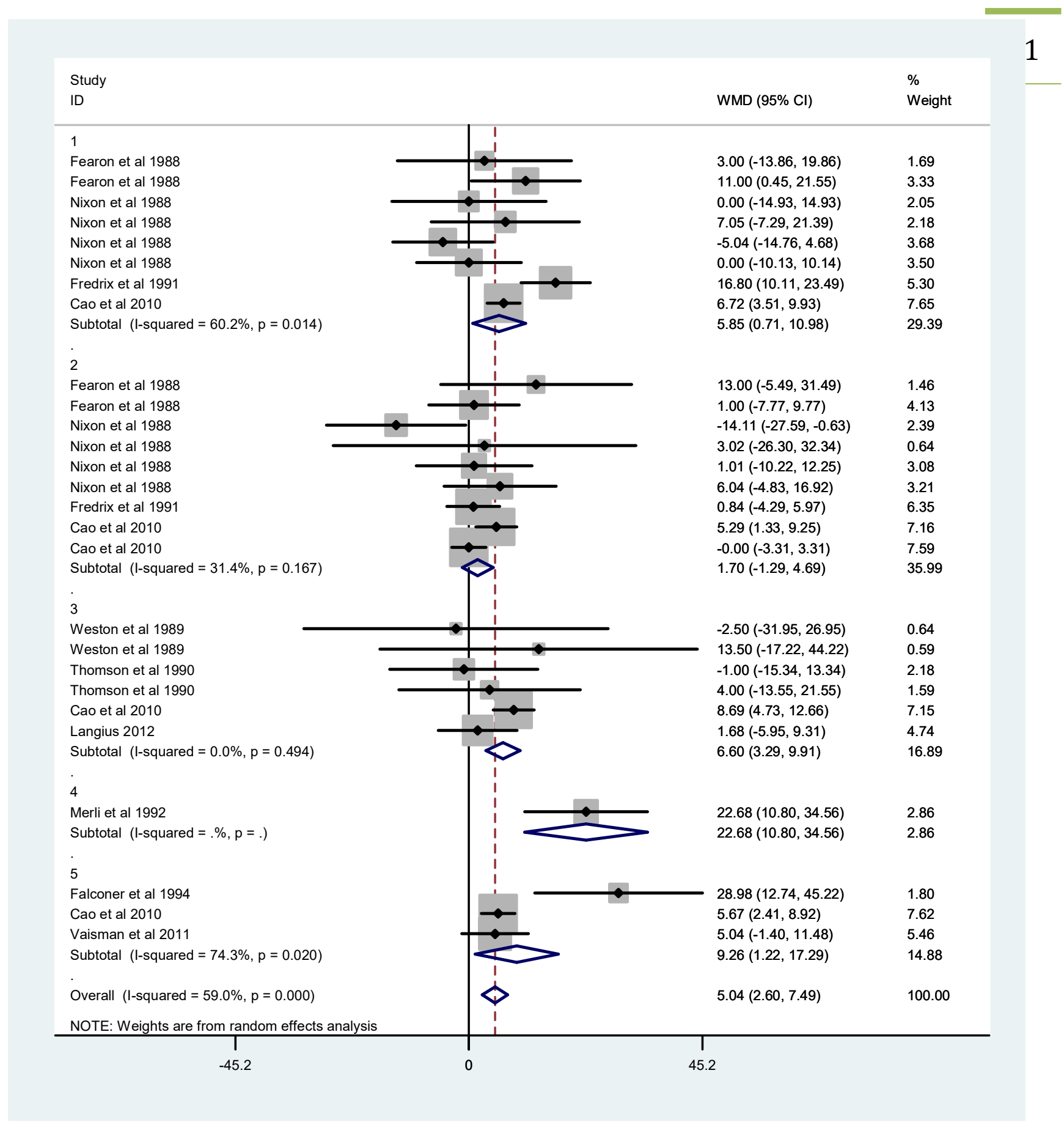

Figure 2. Subgroup analysis showing elevations in REE for each cancer subtype. The size of the shaded squares is proportional to the weight of each study. The horizontal lines represent $95 \% \mathrm{Cl} .{ }^{1}$ Lung; ${ }^{2}$ Gastric/colon; ${ }^{3} \mathrm{Head}$, neck and oesophageal; ${ }^{4}$ Liver; ${ }^{5}$ Pancreatic. Multiple entries from the same paper represent figures presented divided by cancer subtype, weight losing/weight stable and/or sex. 
Figure 3 Funnel Plot

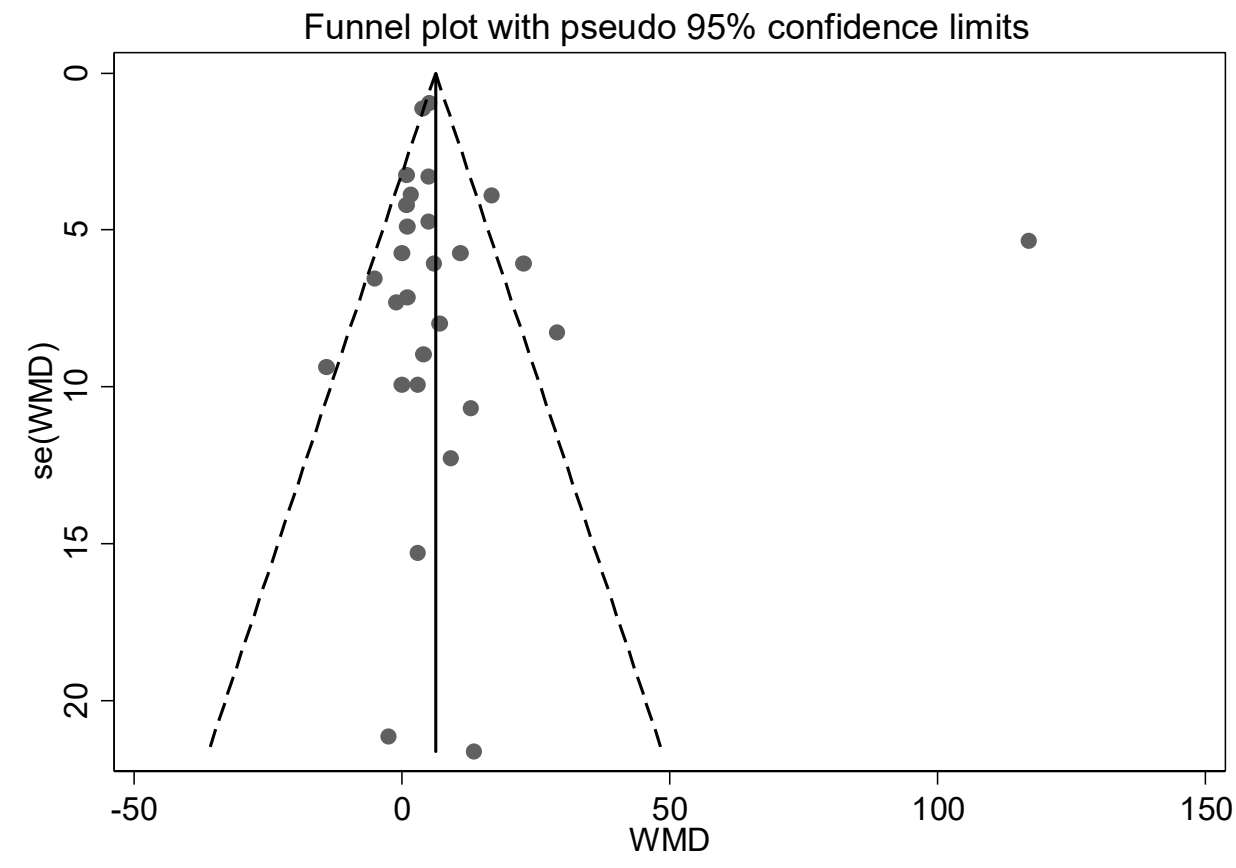


Figure 4

REE cancer subgroups compared with control

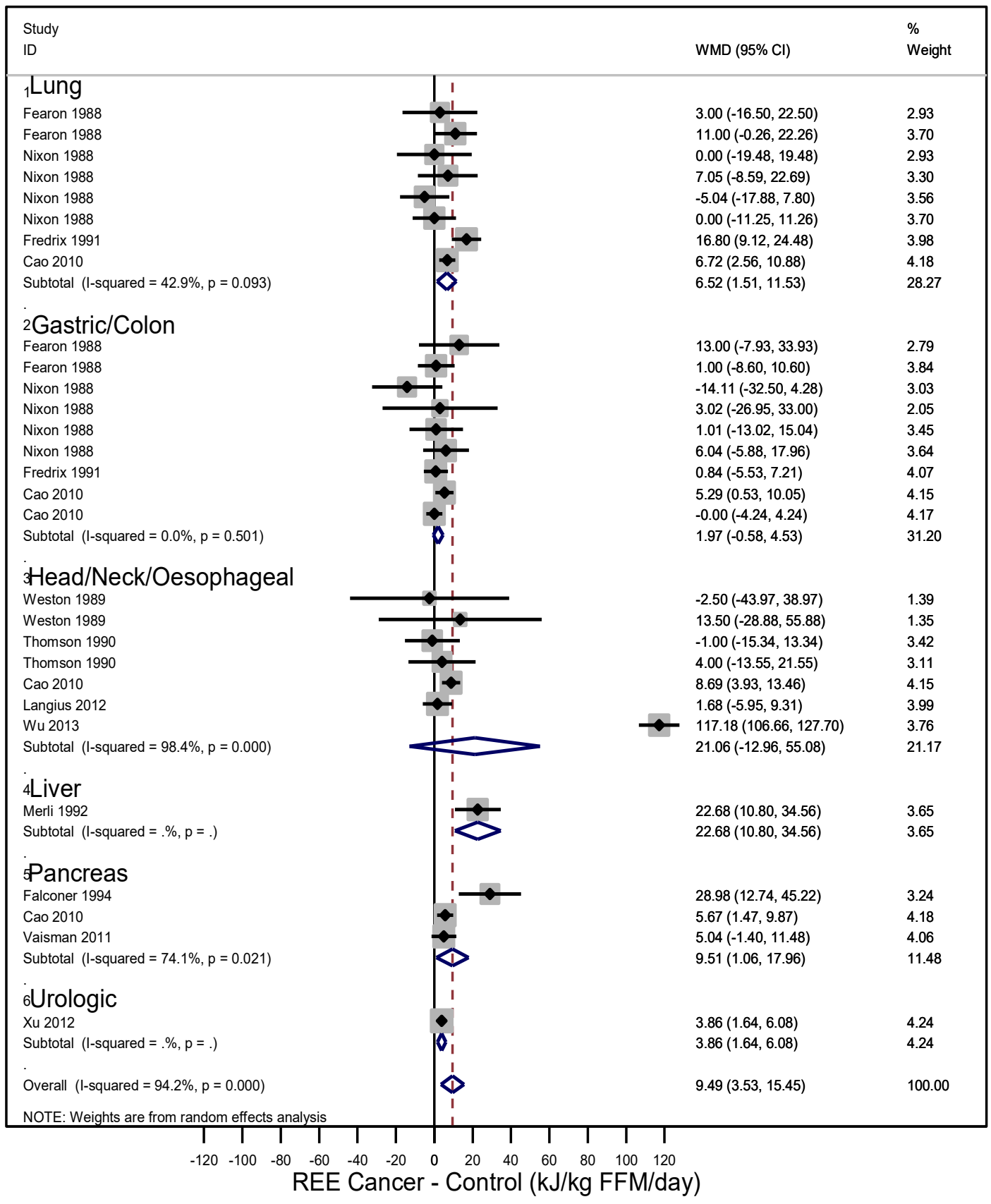

WMD weighted mean difference, se standard error, 1-6, indicates the different cancer types as labelled. 
Figure 5 Funnel plot for subgroup analysis

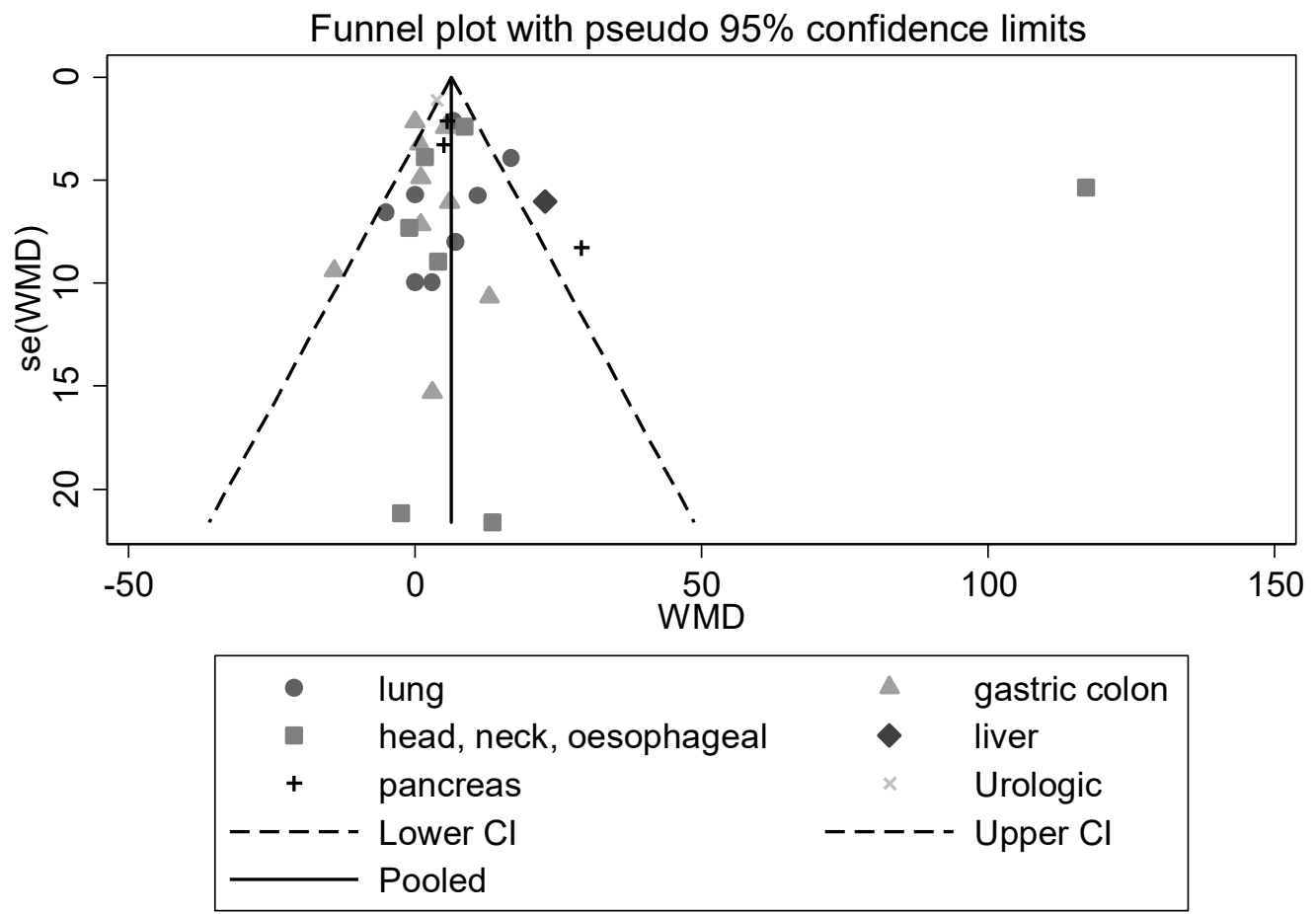

WMD weighted mean difference, se standard error 